\title{
Periodic 1.5 ka climate variations during MIS 2 in the belt of Southern Hemispheric westerlies
}

\author{
Pierre Kliem $^{\mathrm{a} *}$, Henrike Baumgarten ${ }^{\mathrm{b}}$, Catalina Gebhardt ${ }^{\mathrm{c}}$, Annette Hahn ${ }^{\mathrm{d}}$, Christian Ohlendorf ${ }^{\mathrm{a}}$, Bernd Zolitschka ${ }^{\mathrm{a}}$ \\ ${ }^{a}$ University of Bremen, Institute of Geography, Geomorphology and Polar Research (GEOPOLAR), Wiener Strasse 9, D-28359 Bremen, Germany \\ ${ }^{\mathrm{b}}$ Leibniz Institute for Applied Geophysics (LIAG), Stilleweg 2, D-30655 Hannover, Germany \\ ${ }^{\mathrm{c}}$ Alfred Wegener Institute (AWI), Van-Ronzelen-Str. 2, D-27568 Bremerhaven, Germany \\ ${ }^{\mathrm{d}}$ University of Bremen, Center for Marine Environmental Sciences (MARUM), Loebener Straße, D-28359 Bremen, Germany
}

(RECEIVED February 19, 2016; AcCEPTED January 21, 2017)

\begin{abstract}
Lacustrine sediments retrieved from Laguna Potrok Aike in the framework of the Potrok Aike Maar Lake Sediment Archive Drilling Project (PASADO) offer the possibility to investigate climate variations of the past $\sim 51$ cal $\mathrm{ka}$ BP in Southern Hemispheric midlatitudes, Argentinean Patagonia. This study focuses on short-term cyclicities in the Ca and magnetic susceptibility data sets between 51 and $15 \mathrm{cal} \mathrm{ka}$ BP. The record yields a climate pattern with a periodicity of $1.5 \mathrm{ka}$ during Marine Oxygen Isotope Stage 2 (MIS 2) detected in the Southern Hemisphere from 31 to $17 \mathrm{cal}$ ka BP for the first time. MIS 2 is known for constantly cold temperatures, whereas prominent climate variations paced by a $1.5 \mathrm{ka}$ periodicity occurred during MIS 3. Our study documents that minor latitudinal oscillations of the Southern Hemispheric westerlies and the polar easterlies with a $1.5 \mathrm{ka}$ periodicity also took place during MIS 2 . However, we assume that because of a major northward displacement of the Southern Hemispheric westerlies, these oscillations did not sufficiently affect the zone of Circumpolar Deep Waters and an increased greenhouse effect by upwelling of $\mathrm{CO}_{2}$-rich deep waters did not occur. This mechanism illustrates why prominent climate events fail to appear during MIS 2.
\end{abstract}

Keywords: Patagonia; Laguna Potrok Aike; Lake sediments; Frequency analysis; Bond cycles; Dansgaard-Oeschger events; PASADO

\section{INTRODUCTION}

Patagonia has been the focus of paleoclimate research since Caldenius (1932) started to reconstruct past glacier advances in the 1930s. Since then, the number of climate archives and proxies applied to unravel the regional climate history increased distinctly (cf. review of Kilian and Lamy, 2012). During the last decades, studies concentrated on the reconstruction of latitudinal shifts of the Southern Hemispheric westerlies (SHWs) at the Pleistocene-to-Holocene transition (Mayr et al., 2013), as well as on the role of Patagonia as a dust source for the Southern Hemisphere (Petit et al., 1999).

With the discovery of significant variations of dust in Antarctic ice cores during the last $800 \mathrm{ka}$, Patagonia was suggested as the main dust source (Petit et al., 1999; EPICA Community Members, 2004, 2006). This hypothesis is supported by data from

*Corresponding author at: University of Bremen, Institute of Geography, Geomorphology and Polar Research (GEOPOLAR), Wiener Strasse 9, D-28359 Bremen, Germany. E-mail address: kliemp@gmx.de (P. Kliem). geochemical fingerprinting (Grousset et al., 1992; Basile et al., 1997; Gaiero, 2007; Sugden et al., 2009; Delmonte et al., 2010).

Increased Patagonian dust production during the glacial period is related to several factors-for example, increased glacial and fluvial erosion in mountain regions (Petit et al., 1999), exposure of the South American shelf as a potential source area for continental dust (Kaiser and Lamy, 2010), increased proglacial meltwater dynamic (Sugden et al., 2009), and intensified foehn winds increasing aridity (Kaiser and Lamy, 2010) and reducing atmospheric dust outwash (Lambert et al., 2008).

After mobilization at the surface, cyclones elevate aerosols to the upper troposphere where they move to the east and to the southeast as far as $80^{\circ} \mathrm{S}$ (Iriondo, 2000). Here, dusttransporting air masses sink to the ground under the influence of the Antarctic anticyclone. Trajectory studies demonstrate that dust is transported eastward by moving low-pressure systems. Today, this takes about 7 days from Patagonia to East Antarctica (Li et al., 2010) on pathways crossing the Scotia Sea (Fig. 1; Reijmer et al., 2002). Consequently, marine dust records from the Scotia Sea (Fig. 1), located midway between the source region (Patagonia) and 


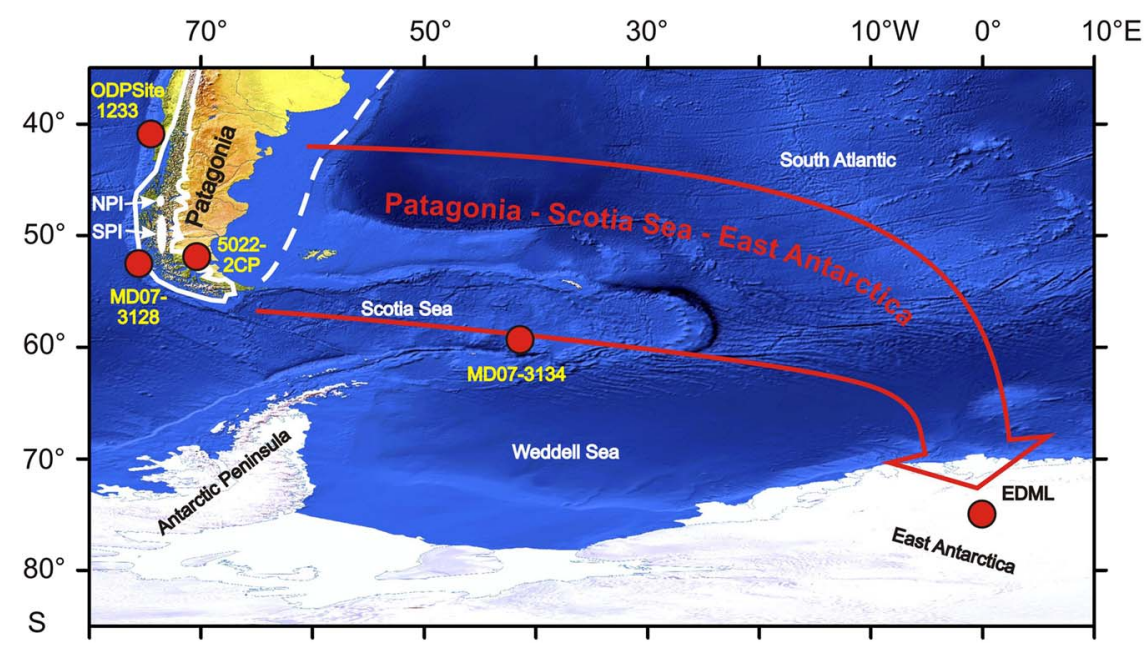

Figure 1. Map with sites mentioned in Figure 3 along the dust trajectory from the South Pacific coast (ODP site 1233, MD07-3128) and Patagonia (5022-2CP) via the Scotia Sea (MD07-3134) to Antarctica (East Antarctic Dronning Maud Land [EDML]). The red arrow indicates the pathway of dust based on a 5-day backward air-parcel trajectory for EDML after Reijmer et al. (2002). Additionally, the extent of the Patagonian shelf during the sea-level lowstand of the last glacial maximum (LGM; Iriondo, 2000) and the limit of the Patagonian Ice Field during the LGM (Hein et al., 2010) are indicated. NPI, modern Northern Patagonian Ice Field; SPI, modern Southern Patagonian Ice Field. (For interpretation of the references to color in this figure legend, the reader is referred to the web version of this article.)

East Antarctica, correlate with Antarctic dust variations (Hofmann, 1999; Weber et al., 2012).

Suitable proxies to compare records are the non-sea salt Ca flux established as an indicator for atmospheric dust variations during glacial times for Antarctic ice cores (Lambert et al., 2011) and the magnetic susceptibility (MS) obtained for the marine record from the Scotia Sea (Hofmann, 1999; Weber et al., 2012). These two proxies have also been suggested to document dust activity for sediments of Laguna Potrok Aike (LPA) at $52^{\circ} \mathrm{S}$, located at the southern limit of the Patagonian dust source region (Haberzettl et al., 2009; Hahn et al., 2014; Lisé-Pronovost et al., 2015).

The main argument for using $\mathrm{Ca}$ and MS as LPA dust proxies is the long-term correlation with regional dust proxies of the Scotia Sea and Antarctica (Haberzettl et al., 2009; Hahn et al., 2014; Lisé-Pronovost et al., 2015). However, the interpretation of MS is complicated because of several confounding factors (Lisé-Pronovost et al., 2015). Ca reflects the dust activity of LPA shore sediments (Hahn et al., 2014). During the Holocene and the late glacial period, autochthonous carbonates were precipitated in the lake (Hahn et al., 2014). For these time intervals, $\mathrm{Ca}$ cannot be used as an indicator for clastic input. However, the glacial sediments deposited between 51 and $15 \mathrm{cal}$ ka BP are carbonate-free (Hahn et al., 2013). Therefore, we focus our study on this time window. Regarding individual limitations, this study analyzed both parameters together. The $\mathrm{Ca}$ record is based on X-ray fluorescence detection and was published by Hahn et al. (2014). The new MS record was obtained by point sensor detection on split cores. For further characterization of the parameters $\mathrm{Ca}$ and MS, the new dry density (DD) record is presented.

This study focuses on the frequency analysis of $\mathrm{Ca}$ and MS records. The analyzed time window from 51 to $15 \mathrm{ka}$ is well known for rapid warming events: Dansgaard-Oeschger (DO) cycles (Dansgaard et al., 1993) from the North Greenland $\delta^{18} \mathrm{O}$ record (North Greenland Ice Core Project) and the Southern Hemisphere (Alley et al., 2001). The location of LPA offers the opportunity to identify short-term climate cycles within the dust source area. Furthermore, Quaternary climate variations, probably expressed as displacements of the SHWs, can be tracked at Southern Hemispheric midlatitudes (Anderson et al., 2009; Toggweiler, 2009).

\section{SITE DESCRIPTION}

LPA is located on the leeside of the Andes in southeastern Patagonia ( $85 \mathrm{~km}$ southwest of the city of Rio Gallegos and $\sim 80 \mathrm{~km}$ north of the Strait of Magellan), Argentina. South of $40^{\circ} \mathrm{S}$, low-level westerly winds prevail over the continent throughout the year (Garreaud, 2009). The upper-level jet stream moves between $45^{\circ} \mathrm{S}$ and $55^{\circ} \mathrm{S}$ during austral summer and between $20^{\circ} \mathrm{S}$ and $40^{\circ} \mathrm{S}$ in winter. Regionally, the amount of precipitation and the strength of westerly winds correlate at the Pacific coast and the western slope of the Andes. This correlation decreases dramatically toward the east and reaches negative values across the Patagonian steppe (Garreaud et al., 2013). Consequently, the west-east precipitation gradient is less prominent in years with weak westerly winds.

Within the $200 \mathrm{~km}^{2}$ semiarid catchment area of LPA (Zolitschka et al., 2006), annual precipitation is $<300 \mathrm{~mm}$ (Mayr et al., 2007b) and reaches $150 \mathrm{~mm}$ at a local meteorological station near LPA (Zolitschka et al., 2006). A recent time series of precipitation measurements (1999-2005) at LPA shows that easterly wind directions (from the South Atlantic) are often combined with precipitation, whereas west winds carry considerable less moisture per rainfall event (Mayr et al., 2007b). Easterly wind directions can be caused 
by atmospheric blocking of the SHWs, which are more likely during winter seasons (Schneider et al., 2003; Garreaud et al., 2013). Furthermore, blocking of SHWs enables cold Antarctic air masses to migrate into Patagonia from the South. The mean annual air temperature at Rio Gallegos (6 meters above sea level [m asl], $85 \mathrm{~km}$ northeast of the study site) is $7.4 \pm 0.7^{\circ} \mathrm{C}$, with a July (winter) minimum of $1.0 \pm 1.5^{\circ} \mathrm{C}$ and a January (summer) maximum of $13.0 \pm 1.2^{\circ} \mathrm{C}$ (Zolitschka et al., 2006). Mean annual wind speeds of $7.4 \mathrm{~m} / \mathrm{s}$ occur at Rio Gallegos with a dominantly western direction (Weischet, 1996; Baruth et al., 1998).

The sediment basin containing LPA is of volcanic origin and resulted from a phreatomagmatic eruption dated to $0.77 \pm 0.24$ Ma by ${ }^{40} \mathrm{Ar} /{ }^{39} \mathrm{Ar}$ (Zolitschka et al., 2006). The area is characterized by extensive backarc volcanism and belongs to the Pali Aike Volcanic Field (Mazzarini and D'Orazio, 2003; Ross et al., 2011). Scoria cones, plateau lavas, and maar volcanoes are common. They are covered by glaciofluvial deposits and basal till of Pliocene to middle Pleistocene glaciations. However, according to geomorphological and stratigraphic evidence, glaciers did not reach the catchment area of LPA at least for the last five glacial periods (Caldenius, 1932; Mercer, 1976; Rabassa and Clapperton, 1990; Meglioli, 1992; Coronato et al., 2013). Widespread sand sheets are the youngest deposits and demonstrate Late Holocene eolian dynamics (Favier-Dubois, 2007; Kliem et al., 2013a).

In a limnological context, LPA is a polymictic and subsaline maar lake (Zolitschka et al., 2006), and clastic sedimentation dominated throughout the past $51 \mathrm{ka}$ (Hahn et al., 2014). In 2003, the lake level was at an elevation of $116 \mathrm{~m}$ asl and had a maximum diameter of $3.5 \mathrm{~km}$ and a water depth of $100 \mathrm{~m}$ (Zolitschka et al., 2006). Numerous subaerial and subaqueous lake-level terraces demonstrate rapid and sizable past hydrologic variations and a paleo-outflow channel related to an exceptional high lake level (Haberzettl et al., 2005, 2007; Anselmetti et al., 2009; Kliem et al., 2013a). Presently, the lake has neither a permanent tributary nor a surficial outflow. Episodic or ephemeral surface runoff enters the lake through gullies mainly after spring snowmelt that deeply eroded into the subaerial terraces (Haberzettl et al., 2005; Mayr et al., 2007a).

\section{METHODS}

\section{Lithology and chronology}

The sediment record of LPA (5022-2CP) with a length of $106.08 \mathrm{~m}$ composite depth was the key site of the International Continental Scientific Drilling Program (ICDP) lake deep drilling expedition 5022 (Potrok Aike Maar Lake Sediment Archive Drilling Project [PASADO]) performed from August to November 2008 (Zolitschka et al., 2009). Site 5022-2CP consists of three different sediment types: pelagic sediments, mass-movement deposits (MMDs), and tephra layers (Kliem et al., 2013b).

Three main lithostratigraphic units (A, B, and C) were distinguished by Kliem et al. (2013b). Sediments of unit A

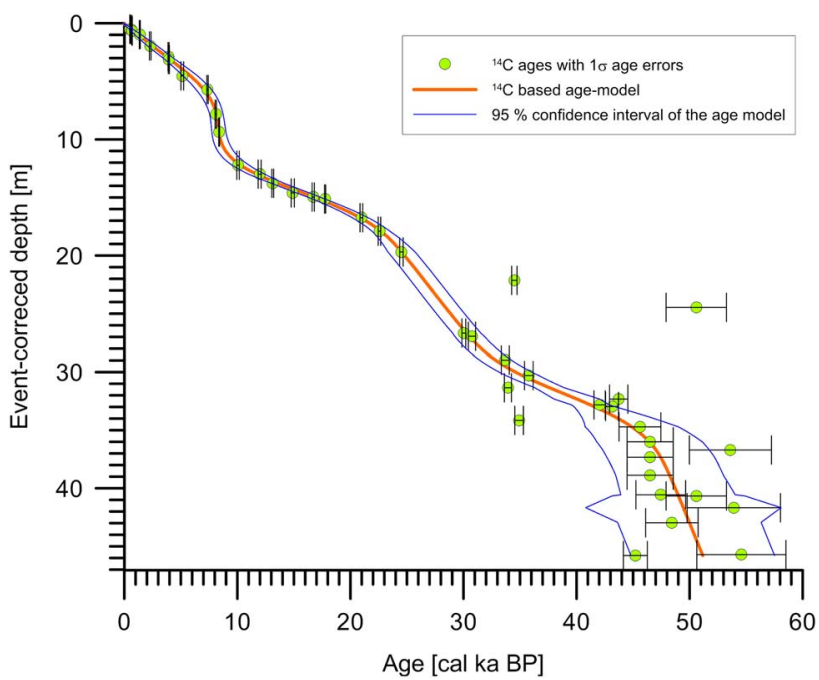

Figure 2. (color online) Radiocarbon-based age model for the eventcorrected (after removal of event deposits with a thickness $>2 \mathrm{~cm}$ ) sediment record of Potrok Aike Maar Lake Sediment Archive Drilling Project site 5022-2CP (modified after Kliem et al., 2013b).

are characterized by laminated silts with inorganic carbonate contents of up to $2 \%$ that were deposited from $8.3 \mathrm{cal} \mathrm{ka} \mathrm{BP}$ to the present day. The highest concentration of plant macroremains occurs in lithostratigraphic unit $\mathrm{B}$, which is characterized by an abrupt onset at $17.2 \mathrm{cal} \mathrm{ka} \mathrm{BP}$; this unit represents the transition from the last glacial period to the early Holocene. Unit $\mathrm{C}$ comprises the glacial time slice of the record from 51.2 to $17.2 \mathrm{cal} \mathrm{ka} \mathrm{BP}$. This unit is composed of pelagic sediments with a down-core increase of MMDs.

The sediments were radiocarbon $\left({ }^{14} \mathrm{C}\right)$ dated, and ages were calibrated applying the CalPal_2007_HULU data set (Weninger and Jöris, 2008). For age modeling, MMDs and tephra layers were excluded from the profile (Fig. 2). The age model of the event-corrected record is based on a mixedeffect regression procedure (Heegaard et al., 2005; Kliem et al., 2013b). The age-depth relationship for the investigated time interval ( 51.2 to $15 \mathrm{cal} \mathrm{ka} \mathrm{BP}$ ) is based on 22 accelerator mass spectrometry ${ }^{14} \mathrm{C}$ dates. However, preliminary correlation of optically stimulated luminescence dates from drill site 1 (Gebhardt et al., 2012; Buylaert et al., 2013) and results from diatom studies (Recasens et al., 2015) support that the record may extend into an older Antarctic warm period (i.e., Antarctic Isotope Maximum [AIM] 14; Fig. 3).

\section{MS and DD}

MS was measured nondestructively at $0.5-\mathrm{cm}$ increments on split core halves using a Bartington point sensor (MS2F) mounted on an automated scanner as described by Funk et al. (2004). In contrast, the data set published by Lisé-Pronovost et al. (2015) was measured on U-channels. DD was calculated from volumetric subsamples that were taken in consecutive $2 \mathrm{~cm}$ increments for the entire sediment sequence. Each subsample was weighed, freeze-dried, and weighed again to obtain $\mathrm{DD}$ values. 


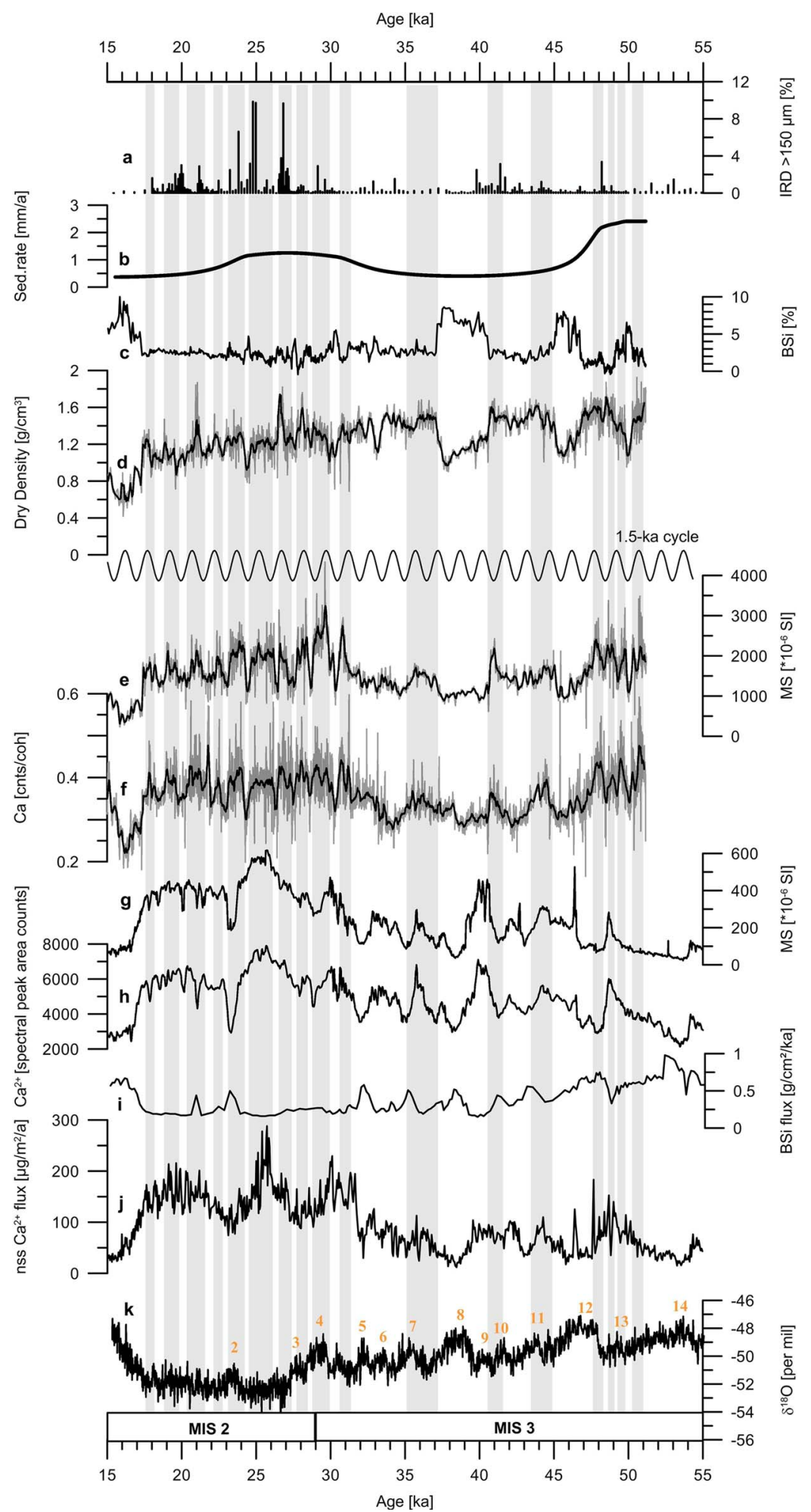

Figure 3. Northwest-southeast transect from the South Pacific entrance of the Magellan Strait to East Antarctica (for location of sites, see Fig. 1). (a) Ice-rafted debris (IRD) at the Pacific entrance of the Magellan Strait (Caniupán et al., 2011). Records from Laguna Potrok Aike (5022-2CP) are displayed from $\mathrm{b}$ to $\mathrm{f}$ with individual data points and the 200-yr running mean as a bold line. (b) Sedimentation rate (Kliem et al., 2013b). (c) Biogenic silica (BSi). (d) Dry density. (e) Magnetic susceptibility (MS). (f) X-ray fluorescence (XRF) calcium (Ca) (c and f: Hahn et al., 2014). (g-i) Scotia Sea sediment core MD07-3134 (g and h: Weber et al., 2012): MS (g), XRF-Ca (h), and BSi flux (i) (Sprenk et al., 2013). (j) East Antarctic Dronning Maud Land (EDML) non-sea salt (nss) Ca flux (Fischer et al., 2007). (k) EDML $\delta^{18} \mathrm{O}$ including orange-numbered Antarctic Isotope Maxima (EPICA Community Members, 2006, 2010). Intervals with increased Ca and MS for 5022-2CP are shaded. An ideal $1.5 \mathrm{ka}$ cycle is represented by the sinusoidal curve between d and e for comparison. MIS, Marine Oxygen Isotope Stage. (For interpretation of the references to color in this figure legend, the reader is referred to the web version of this article.) 


\section{Spectral analysis}

Cycles in sediment records can be studied by cyclostratigraphic methods (Prokopenko et al., 2001; Weedon, 2003; Lenz et al., 2011). The cyclic nature of a sedimentary sequence is investigated by spectral analysis. The spectral analysis is calculated for a certain interval that is defined by the window size. After the interval was analyzed, the window is shifted downward continuously at a specific step size. The calculation is repeated, and the results are displayed at the center of each window, resulting in a three-dimensional (3D) spectral plot (Molinie and Ogg, 1990; Wonik, 2001; Weedon, 2003; Baumgarten and Wonik, 2015).

For MS and Ca of the LPA sediment record, a spectral analysis is calculated for an interval of specific duration ( window size $=14 \mathrm{ka}$ ), and the window is moved downward continuously with a step size of $1 \mathrm{ka}$. The analysis is repeated at consecutive intervals, and spectra are displayed at the central depth of each window. Results are presented in a 3D spectral plot. The optimal window size was determined by empirical testing.

Generally, a small window size maximizes the length of the resulting plot. However, the contained signal needs to be covered and cannot be determined if a window size is chosen that is too small (e.g., only half of the signal length). Based on the age-depth relationship (Kliem et al., 2013b), the data were analyzed from 51.2 to $15 \mathrm{cal} \mathrm{ka}$ BP. For this study, $200 \mathrm{yr}$ running means of the new MS and published $\mathrm{Ca}$ (Hahn et al., 2014) data were analyzed.

As spectral analysis by sliding window method can be applied on evenly spaced data only, the unevenly spaced data sets were resampled by linear interpolation prior to further analysis. Spectral analysis for identification of characteristic periodicities (Jenkins and Watts, 1969; Priestley, 1981) was performed as fast Fourier transform using MATLAB (MathWorks ${ }^{\circledR}$ ).

\section{RESULTS}

To detect sedimentary cycles, continuous sedimentation is required. Therefore, all presented data are based on the eventcorrected composite profile of LPA (Kliem et al., 2013b). Because of the location of the drill site within the flat profundal zone of the lake (accumulation area of MMDs), a neglectable erosion of pelagic sediments by mass-movement events is assumed.

\section{DD, Ca and MS}

The DD record of LPA sediments reflects a minor compaction trend and ranges from $0.6 \mathrm{~g} / \mathrm{cm}^{3}$ at $\sim 16 \mathrm{cal} \mathrm{ka} \mathrm{BP}$ to $1.5 \mathrm{~g} / \mathrm{cm}^{3}$ at $\sim 48$ cal ka BP (Fig. 3d). This trend is interrupted by decreases in DD of $\sim 0.5 \mathrm{~g} / \mathrm{cm}^{3}$ for four periods: (1) $51.0-49.0 \mathrm{cal} \mathrm{ka} \mathrm{BP}$, (2) 46.9-45.1 cal ka BP, (3) 40.5-37.1 cal ka BP, and (4) 17.5$15 \mathrm{cal} \mathrm{ka}$ BP. The same intervals are characterized by increased biogenic silica (BSi) values (Fig. 3c) published by Hahn et al. (2013). Both parameters exhibit an anticorrelation $(r=-0.62)$.

The records of DD and MS correlate weakly $(r=0.51$ for a $200 \mathrm{yr}$ running mean). Moreover, DD shows no correlation with $\mathrm{Ca}(r=0.33)$. A good correlation was only identified between $\mathrm{Ca}$ and MS $(r=0.78)$.

\section{Spectral analysis}

The 3D spectral plots of $\mathrm{Ca}$ and MS range from 44 to $22 \mathrm{cal}$ ka BP because half of the window length of $14 \mathrm{ka}$ cannot be displayed. For both records, different high amplitudes have been detected, whereas the frequency of $1.5 \mathrm{ka}$ occurs in both data sets.

The 3D spectral plot of the MS data (Fig. 4a) documents the $1.5 \mathrm{ka}$ cycle starting at ca. $36 \mathrm{cal} \mathrm{ka}$ BP with an increased amplitude toward the top. An additional cycle of 6 ka occurs in the youngest section, establishes with increasing energy, and persists toward the top.

The sliding window plot of the Ca data (Fig. 4b) shows that the $1.5 \mathrm{ka}$ cycle establishes around $36 \mathrm{cal} \mathrm{ka} \mathrm{BP}$ with an increasing energy level toward the top of the analyzed time interval. The amplitude of $3.0 \mathrm{ka}$ has high energy prior to $36 \mathrm{cal}$ ka BP, weakens afterward, and reoccurs around $25 \mathrm{ka}$.

\section{DISCUSSION}

\section{Ca and MS}

$\mathrm{Ca}$ and MS records of LPA reflect chemical/magnetic changes of the clastic input during the glacial period (Hahn et al., 2014; Lisé-Pronovost et al., 2015). Ca is mainly derived from eroded local basaltic rocks and accumulates as shore sediment (Hahn et al., 2014). During low lake levels, strong winds triggered the transport of basaltic sand from the lakeshore to the lake center. The identification of the source of clastic input with high values of MS is complicated because of several confounding factors (Lisé-Pronovost et al., 2015). However, because of a good visual coincidence (Fig. 3e and f) and a good correlation between $\mathrm{Ca}$ and MS $(r=0.78)$, MS very likely also reflects dust input blown out by strong winds from basaltic shore sediments.

Strong winds (deduced from high levels of $\mathrm{Ca}$ and MS) likely result from intensified katabatic winds because of glacier advances of the Southern Patagonian Ice Field (SPI; Fig. 1) covering large areas of the eastern Andean foreland. Data from a record of ice-rafted debris in the Pacific support a coincidence of SPI dynamics (Fig. 3a) with $\mathrm{Ca}$ and MS records (Fig. 3e and f). The glacier dynamics of the SPI likely reflect climate variations because of shifts of the atmospheric circulation (Caniupán et al., 2011). Glacier advances were associated with the influence of the polar easterlies, whereas glacier retreats reflect intensified SHWs.

Very strong SHWs during AIM 12 and AIM 8 were also inferred from high levels of the lacustrine paleoproductivity indicator BSi (Fig. 3c; Hahn et al., 2013) and coincide 

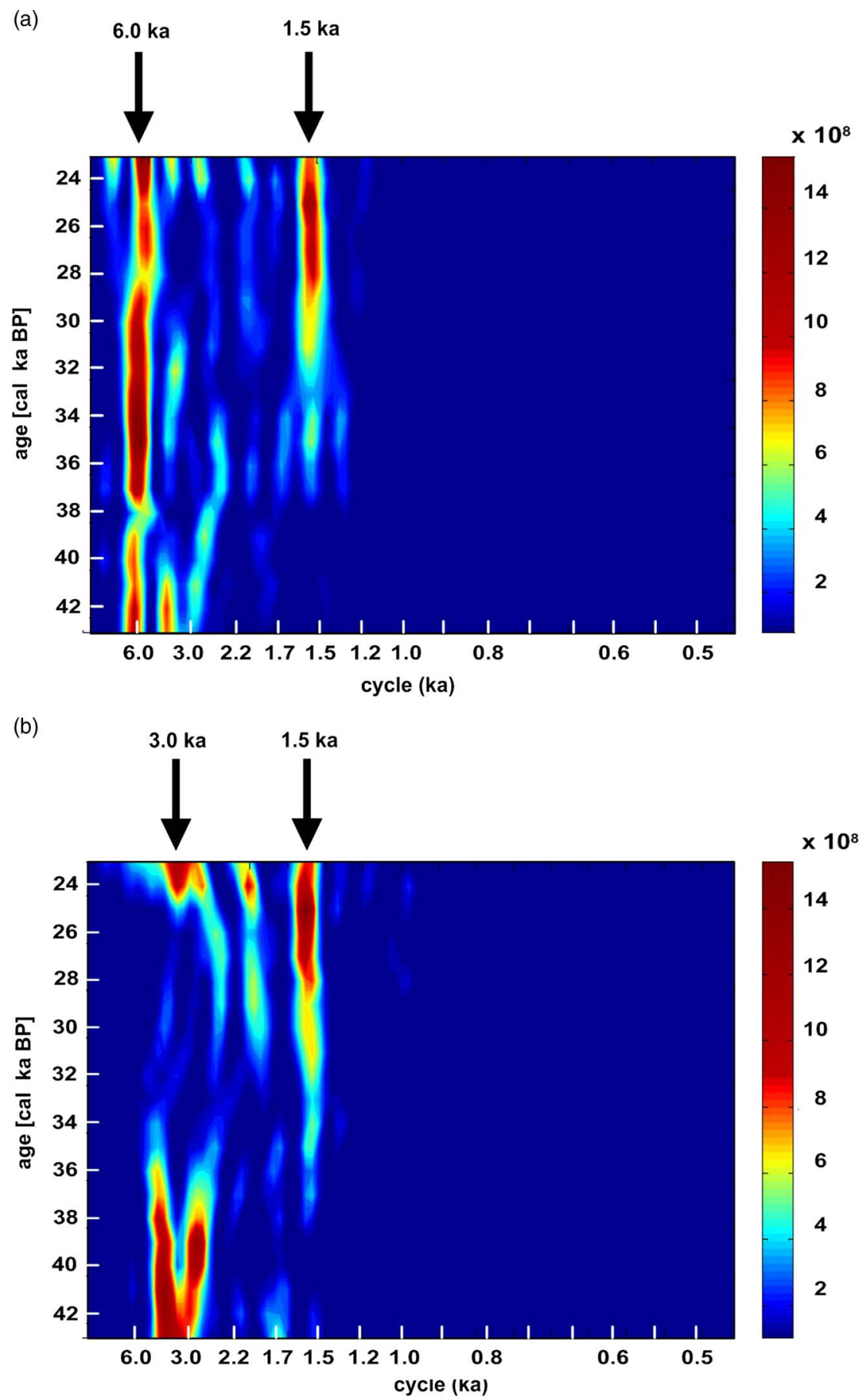

Figure 4. (color online) Three-dimensional spectral plots of magnetic susceptibility (a) and Ca (b) data for the last glacial period (51.2 to $15 \mathrm{cal} \mathrm{ka} \mathrm{BP})$. Dominant cycles are labeled with their frequency.

with very low $\mathrm{Ca}$ and MS levels (i.e., with a glacier retreat). The DD of the sediment likely decreased because of the high content of BSi $(r=-0.62)$. Thus, low $\mathrm{Ca}$ and MS levels because of dilution effects by high $\mathrm{BSi}$ content or other nonclastic compounds cannot be excluded during these periods.

$\mathrm{Ca}$ and MS variations of the clastic component in the LPA sediment record are indirectly linked to shifts of the polar easterlies and the SHWs. Increased Ca and MS levels reflect intensified easterlies, whereas decreased $\mathrm{Ca}$ and MS reflect intensified SHWs.

\section{A robust 1.5 ka periodicity dominates MIS 2}

The parameters MS and Ca document a 1.5 ka cycle from 36 to $22 \mathrm{cal} \mathrm{ka} \mathrm{BP}$ (Fig. 4). However, because of the $14 \mathrm{ka}$ spectral time window the center of the spectral analysis is 


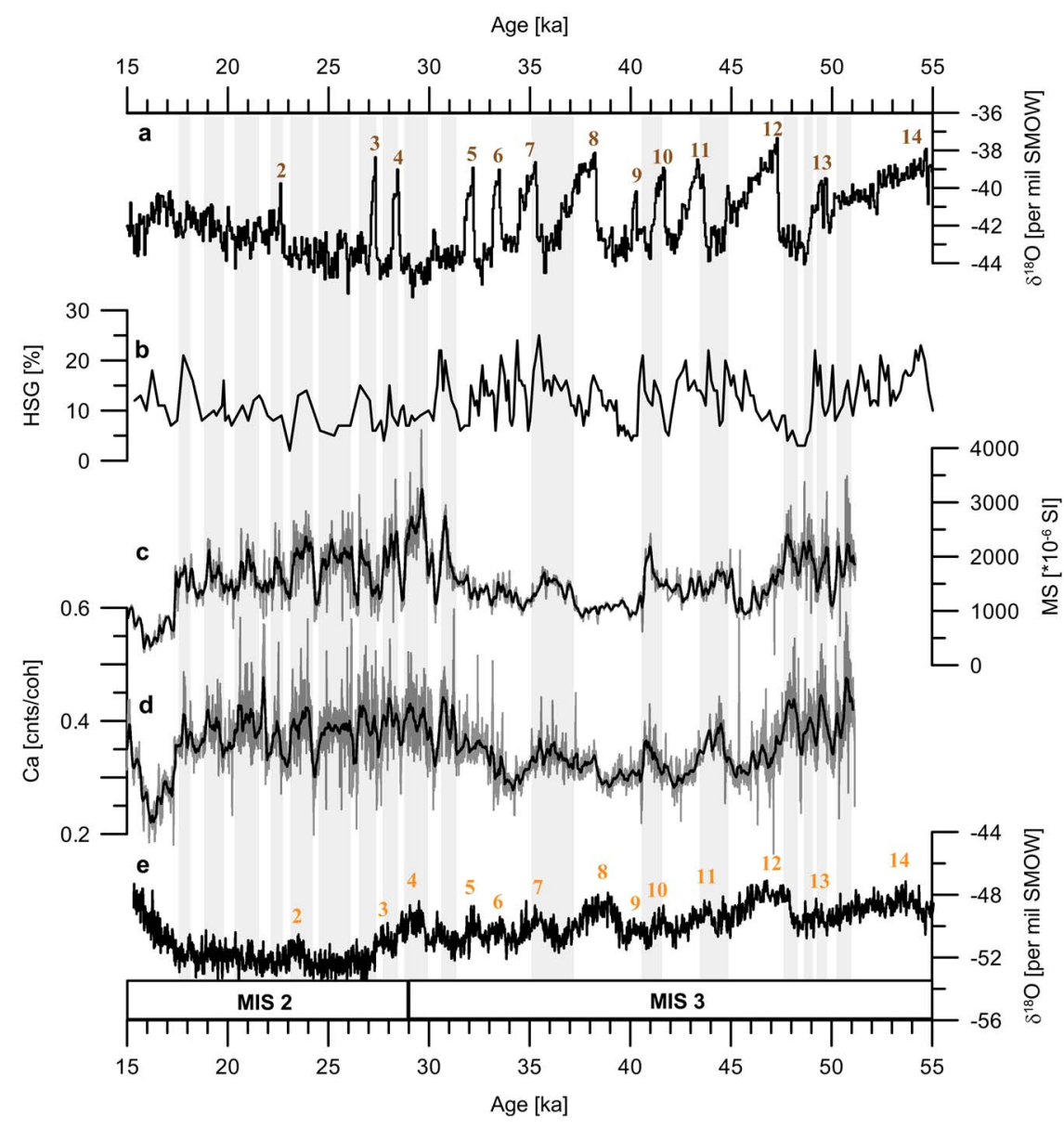

Figure 5. North-south transect from Greenland via the Atlantic Ocean to East Antarctica. (a) Northern Hemisphere (North Greenland Ice Core Project) $\delta^{18} \mathrm{O}$ (per mil Standard Mean Ocean Water [SMOW]) including brown-numbered Dansgaard-Oeschger cycles (North Greenland Ice Core Project members, 2004). (b) Hematite-stained grains (HSG) of ice-rafted debris records recovered from the North Atlantic at 50 $\mathrm{N}$ (Bond et al., 1999) with updated chronology (Obrochta et al., 2012). (c and d) Laguna Potrok Aike (5022-2CP) with individual magnetic susceptibility (MS) and Ca data points and the respective $200 \mathrm{yr}$ running means as bold lines. (e) East Antarctic Dronning Maud Land $\delta^{18} \mathrm{O}$ including orange-numbered Antarctic Isotope Maxima (EPICA Community Members, 2006, 2010). Intervals with increased $\mathrm{Ca}$ and MS for 5022-2CP are shaded. (For interpretation of the references to color in this figure legend, the reader is referred to the web version of this article.)

limited to $22 \mathrm{cal} \mathrm{ka} \mathrm{BP,} \mathrm{even} \mathrm{if} \mathrm{including} \mathrm{data} \mathrm{up} \mathrm{to} 15 \mathrm{cal} \mathrm{ka}$ BP. Indeed, the distinct $1.5 \mathrm{ka}$ signal is visually traceable between 31 and 17 cal ka BP (Fig. 3e and f).

Persistent 1-2 ka climate cyclicities during MIS 3 and MIS 2 show a mean periodicity of $1476 \mathrm{yr} \pm 585 \mathrm{yr}(1 \sigma)$ between 65 and $15 \mathrm{ka}$ at site DSDP 609. They were inferred from hematite-stained grains of ice-rafted debris (IRD-HSG) records recovered from the North Atlantic $\left(50^{\circ} \mathrm{N}\right)$ and were suggested to pace DO events known from Greenland ice cores (Bond et al., 1999). A chronology update and statistical analysis on the classic DSDP 609 data sets revised earlier results and showed that the original $\sim 1.5 \mathrm{ka}$ periodicity is a mixture of two cyclicities ( 1000 yr and $\sim 2000 \mathrm{yr}$; Obrochta et al., 2012). Moreover, and not corresponding to LPA, a $\sim 2$ ka cyclicity prevails between 30 and $22 \mathrm{ka}$.

The difference between LPA and the reinterpreted DSDP 609 record is of major scientific interest regarding ongoing discussions about the origin of this 1-2 ka periodicity. A combination of different solar frequencies (Braun et al., 2005;
Clemens, 2005) might be an explanation for the origin of a $1.5 \mathrm{ka}$ periodicity. However, Holocene atmospheric ${ }^{14} \mathrm{C}$ production rates and ice core ${ }^{10} \mathrm{Be}$ fluxes suggest solar variations with periodicities of $\sim 1000$ and $2000 \mathrm{yr}$ (Obrochta et al., 2012). It is possible that variations of the geomagnetic field modified this pattern at least for the Holocene (St-Onge et al., 2003; Snowball and Muscheler, 2007).

The LPA record reveals a robust $\sim 1.5 \mathrm{ka}$ climate periodicity prevailing during MIS 2. If the reinterpretation of DSDP 609 reports the same climate signal, differences might result from climate cycles not recovered at the North Atlantic IRD-HSG sites or from chronological uncertainties (Fig. 2). For comparison, expected $1.5 \mathrm{ka}$ paced DO events often fail during MIS 3 (Schulz, 2002). Alley et al. (2001) explained this property of Arctic and Antarctic ice-core records with stochastic resonance-that is, the climate switches between warm and cold if a combination of a weak periodicity plus noise reach a certain threshold (the noise characteristic is of importance and summarizes all relevant factors). 


\section{Implications for atmospheric circulations}

The $1.5 \mathrm{ka}$ periodicity dominates MIS 2 and occurs with diminished power during the late MIS 3 at LPA. In contrast, distinct climate variations paced by an $\sim 1.5$ ka periodicity were only dominant during MIS 3 in the polar regions (Grootes and Stuiver, 1997) and not during the constantly cold temperatures of MIS 2 (Fig. 5a and e). Why did the $1.5 \mathrm{ka}$ paced climate variations not occur during MIS 2 in the Antarctic?

Recently, the displacement of the SHWs was linked with Quaternary climate variations. As a poleward shift of the SHWs increases upwelling of the circumpolar deep waters, the released $\mathrm{CO}_{2}$-rich deep waters influence the greenhouse effect (Anderson et al., 2009; Toggweiler, 2009). Increased upwelling identified in the Southern Ocean coincides with the distinct warm events of AIM 8 and AIM 12 (Anderson et al., 2009). Frequent upwelling during MIS 3 has also been inferred from Scotia Sea BSi fluxes (Fig. 3i; Sprenk et al., 2013). In contrast, upwelling in the Scotia Sea was distinctly reduced during MIS 2. With the SHWs in a much more northerly position during MIS 2 , it is possible that the (minor) latitudinal shifts paced by a $1.5 \mathrm{ka}$ periodicity of this wind system did not reach the required latitude to release $\mathrm{CO}_{2}$-rich deep waters into the atmosphere. Therefore, an increased greenhouse effect did not occur, and thus the prominent climate signals disappeared.

In contrast, the provenance changes of the detrital input at LPA reflect a climate signal with a $1.5 \mathrm{ka}$ periodicity during MIS 2. Glacier advances of the SPI suggest a northward displacement of the SHWs that probably increased the influence of polar easterlies delivering cold and/or wet air masses to southern Patagonia. The influence of polar easterlies decreased during minor southward displacements with a $1.5 \mathrm{ka}$ periodicity, resulting in temporary temperature increases and/or precipitation decreases. Periodic $1.5 \mathrm{ka}$ provenance changes did not occur under an overall southward displacement of the SHWs during MIS 3.

However, the episodic $3 \mathrm{ka}(\mathrm{Ca})$ and the persistent $6 \mathrm{ka}$ (MS) periodicities (multiples of the 1.5 ka periodicity; Fig. 4) suggest that provenance changes respond to a $1.5 \mathrm{ka}$ pacing even during MIS 3. However, inconsistencies between $\mathrm{Ca}$ and MS spectral plots, fewer recurrences, and increased dating errors at the limit of the radiocarbon dating method (Fig. 2) complicate the interpretation of these frequencies.

\section{CONCLUSIONS}

The Ca and MS records reflect strong wind-triggered dust input of basaltic shore sediments to the lake. Strong winds likely result from intensified katabatic winds caused by an expansion of the SPI into the eastern Andean foreland. The SPI glaciers advanced because of an increased influence of the easterlies (= $\mathrm{Ca}$ and MS increase in LPA sediments), whereas glacier retreats suggest intensified SHWs (= Ca and MS decrease in LPA sediments).

Based on spectral analysis of $\mathrm{Ca}$ and MS records, a strong $1.5 \mathrm{ka}$ periodicity during MIS 2 (31-17 cal ka BP) has been identified for the first time in the Southern Hemisphere. Our data support a link between the latitudinal position of the SHWs band, greenhouse gas emission from the Antarctic bottom waters, and thus global climate variations. Because of a major northward displacement of the SHWs during MIS 2, the zone of $\mathrm{CO}_{2}$-rich deep water was not sufficiently affected by the SHWs. Therefore, an increased greenhouse effect caused by intensified upwelling did not occur at this time, which resulted in the constantly cold climate of MIS 2 .

During MIS 3, however, an overall southward displacement of the SHWs increased the probability of upwelling driven by minor latitudinal shifts of the SHWs. A $1.5 \mathrm{ka}$ periodicity paces these small-scale shifts and thus the prominent climate signal. This southward displacement caused a general change of the geodynamic framework in the catchment, and the dominance of SHWs probably also reduced the influence of polar easterlies. This finally stopped provenance variations with $1.5 \mathrm{ka}$ periodicity at LPA.

\section{ACKNOWLEDGMENTS}

This research is supported by the ICDP in the framework of the PASADO ("Potrok Aike Maar Lake Sediment Archive Drilling Project"). Funding for drilling was provided by the ICDP, the German Science Foundation (DFG ZO 102/11-1,2), the Swiss National Funds, the Natural Sciences and Engineering Research Council of Canada, the Swedish Vetenskapsradet, and the University of Bremen.

\section{REFERENCES}

Alley, R.B., Anandakrishnan, S., Jung, P., 2001. Stochastic resonance in the North Atlantic. Paleoceanography 16, $57-68$.

Anderson, R.F., Ali, S., Bradtmiller, L.I., Nielsen, S.H.H., Fleisher, M.Q., Anderson, B.E., Burckle, L.H., 2009. Wind-driven upwelling in the Southern Ocean and the deglacial rise in atmospheric $\mathrm{CO}_{2}$. Science 323, 1443-1448.

Anselmetti, F.S., Ariztegui, D., De Batist, M., Gebhardt, A.C., Haberzettl, T., Niessen, F., Ohlendorf, C., Zolitschka, B., 2009. Environmental history of southern Patagonia unravelled by the seismic stratigraphy of Laguna Potrok Aike. Sedimentology 56, 873-892.

Baruth, B., Endlicher, W., Hoppe, P., 1998. Climate and desertification processes in Patagonia. Bamberger Geographische Schriften 15, 307-320.

Basile, I., Grousset, F.E., Revel, M., Petit, J.R., Biscaye, P.E., Barkov, N.I., 1997. Patagonian origin of glacial dust deposited in East Antarctica (Vostok and Dome C) during glacial stages 2, 4 and 6. Earth and Planetary Science Letters 146, 573-589.

Baumgarten, H., Wonik, T., 2015. Cyclostratigraphic studies of sediments from Lake Van (Turkey) based on their uranium contents obtained from downhole logging and paleoclimatic implications. International Journal of Earth Sciences 104, 1639-1654.

Bond, G.C., Showers, W., Elliot, M., Evans, M., Lotti, R., Hajdas, I., Bonani, G., Johnson, S., 1999. The North Atlantic's 1-2 kyr climate rhythm: relation to Heinrich events, Dansgaard/ Oeschger cycles and the Little Ice Age. In: Clark, P.U., 
Webb, R.S., Keigwin, L.D. (Eds.), Mechanisms of Global Climate Change at Millennial Time Scales. Geophysical Monograph 112. American Geophysical Union, Washington, DC, pp. 35-58.

Braun, H., Christl, M., Rahmstorf, S., Ganopolski, A., Mangini, A., Kubatzki, C., Roth, K., Kromer, B., 2005. Possible solar origin of the 1470-year glacial climate cycle demonstrated in a coupled model. Nature 438, 208-211.

Buylaert, J.P., Murray, A.S., Gebhardt, C., Sohbati, R., Ohlendorf, C., Thiel, C., Zolitschka, B., the PASADO Science Team, 2013. Luminescence dating of the PASADO core 5022-1D from Laguna Potrok Aike (Argentina) using IRSL signals from feldspar. Quaternary Science Reviews 71, 70-80.

Caldenius, C., 1932. Las glaciaciones cuarternarias en la Patagonia y Tierra del Fuego. Geografisker Annaler 22, 1-164.

Caniupán, M., Lamy, F., Lange, B., Kaiser, J., Arz, H., Kilian, R., Urrea, O.B., et al., 2011. Millennial-scale sea surface temperature and Patagonian Ice Sheet changes off southernmost Chile $\left(53^{\circ} \mathrm{S}\right)$ over the past 60 kyr. Paleoceanography 26, PA3221. http:// dx.doi.org/10.1029/2010PA002049.

Clemens, S.C., 2005. Millennial-band climate spectrum resolved and linked to centennial-scale solar cycles. Quaternary Science Reviews 24, 521-531.

Coronato, A., Ercolano, B., Corbella, H., Tiberi, P., 2013. Glacial, fluvial and volcanic landscape evolution in the Laguna Potrok Aike maar area, southernmost Patagonia, Argentina. Quaternary Science Reviews 71, 13-26.

Dansgaard, W., Johnsen, S.J., Clausen, H.B., Dahl-Jensen, D., Gundestrup, N.S., Hammer, C.U., Hvidberg, C.S., et al., 1993. Evidence for general instability of past climate from a $250-\mathrm{kyr}$ ice-core record. Nature 364, 218-220.

Delmonte, B., Andersson, P.S., Schöberg, H., Hansson, M., Petit, J.R., Delmas, R., Gaiero, D.M., Maggi, V., Frezzotti, M., 2010. Geographic provenance of aeolian dust in East Antarctica during Pleistocene glaciations: preliminary results from Talos Dome and comparison with East Antarctic and new Andean ice core data. Quaternary Science Reviews 29, 256-264.

EPICA Community Members, 2004. Eight glacial cycles from an Antarctic ice core. Nature 429, 623-628.

EPICA Community Members, 2006. One-to-one coupling of glacial climate variability in Greenland and Antarctica. Nature 444, 195-198.

EPICA Community Members, 2010. Stable oxygen isotopes of ice core EDML. PANGAEA. http://dx.doi.org/10.1594/PANGAEA. 754444.

Favier-Dubois, C.M., 2007. Soil genesis related to medieval climatic fluctuations in southern Patagonia and Tierra del Fuego (Argentina): chronological and paleoclimatic considerations. Quaternary International 162-163, 158-165.

Fischer, H., Fundel, F., Ruth, U., Twarloh, B., Wegner, A., Udisti, R., Becagli, S., et al., 2007. EPICA EDML chemical concentrations and fluxes. PANGAEA. http://dx.doi.org/10.1594/PANGAEA. 683642.

Funk, J.A., von Dobeneck, T., Reitz, A., 2004. Integrated rock magnetic and geochemical quantification of redoxomorphic iron mineral diagenesis in Late Quaternary sediments from the equatorial Atlantic. In: Wefer, G., Mulitza, S., Ratmeyer, V. (Eds.), The South Atlantic in the Late Quaternary: Reconstruction of Material Budgets and Current Systems. Springer-Verlag, Berlin, pp. 237-260.

Gaiero, D.M., 2007. Dust provenance in Antarctic ice during glacial periods: from where in southern South America? Geophysical Research Letters 34, 107-120.
Garreaud, R., Lopez, P., Minvielle, M., Rojas, M., 2013. Largescale control on the Patagonian climate. Journal of Climate 26, 215-230.

Garreaud, R.D., Vuille, M., Compagnucci, R., Marengo, J., 2009. Present-day South American climate. Palaeogeography, Palaeoclimatology, Palaeoecology 281, 180-195.

Gebhardt, C., Ohlendorf, C., Buylaert, J.-P., the PASADO Science Team, 2012. Inter- and intrasite comparison between sites 1 and 2, PASADO deep drilling project - lake evolution, local paleoclimate history, OSL age information. In: Zolitschka, B. (Ed.), 4th International PASADO Workshop, Bremen (Germany), August 27-29, 2012: Program and Abstracts. Terra Nostra 2012/2. GeoUnion Alfred-Wegener-Stiftung, Berlin, pp. 17-18.

Grootes, P.M., Stuiver, M., 1997. Oxygen 18/16 variability in Greenland snow and ice with $10^{-3}$ - to $10^{5}$-year time resolution. Journal of Geophysical Research 102, 26455-26470.

Grousset, F.E., Biscaye, P.E., Revel, M., Petit, J.-R., Pye, K., Joussaume, S., Jouzel, J., 1992. Antarctic (Dome C) ice-core dust at 18 k.y. B.P.: isotopic constraints on origins. Earth and Planetary Science Letters 111, 175-182.

Haberzettl, T., Anselmetti, F.S., Bowen, S.W., Fey, M., Mayr, C., Zolitschka, B., Ariztegui, D., et al., 2009. Late Pleistocene dust deposition in the Patagonian steppe - extending and refining the paleoenvironmental and tephrochronological record from Laguna Potrok Aike back to 55 ka. Quaternary Science Reviews 28, 2927-2939.

Haberzettl, T., Corbella, H., Fey, M., Janssen, S., Lücke, A., Mayr, C., Ohlendorf, C., et al., 2007. Lateglacial and Holocene wet-dry cycles in southern Patagonia: chronology, sedimentology and geochemistry of a lacustrine record from Laguna Potrok Aike, Argentina. Holocene 17, 297-310.

Haberzettl, T., Fey, M., Lücke, A., Maidana, N., Mayr, C., Ohlendorf, C., Schäbitz, F., Schleser, G.H., Wille, M., Zolitschka, B., 2005. Climatically induced lake level changes during the last two millennia as reflected in sediments of Laguna Potrok Aike, southern Patagonia (Santa Cruz, Argentina). Journal of Paleolimnology 33, 283-302.

Hahn, A., Kliem, P., Ohlendorf, C., Zolitschka, B., Rosen, P., the PASADO Science Team, 2013. Climate induced changes as registered in inorganic and organic sediment components from Laguna Potrok Aike (Argentina) during the past $51 \mathrm{ka}$. Quaternary Science Reviews 71, 154-166.

Hahn, A., Kliem, P., Ohlendorf, C., Zolitschka, B., Rosén, P., the PASADO Science Team, 2014. Elemental composition of the Laguna Potrok Aike sediment sequence reveals paleoclimatic changes over the past $51 \mathrm{ka}$ in southern Patagonia, Argentina. Journal of Paleolimnology 52, 349-366.

Heegaard, E., Birks, H.J.B., Telford, R.J., 2005. Relationships between calibrated ages and depth in stratigraphical sequences: an estimation procedure by mixed-effect regression. Holocene 15 , 612-618.

Hein, A.S., Hulton, N.R.J., Dunai, T.J., Sugden, D.E., Kaplan, M.R., $\mathrm{Xu}, \mathrm{S} ., 2$ 2010. The chronology of the Last Glacial Maximum and deglacial events in central Argentine Patagonia. Quaternary Science Reviews 29, 1212-1227.

Hofmann, A., 1999. Kurzfristige Klimaschwankungen im Scotiameer und Ergebnisse zur Kalbungsgeschichte der Antarktis während der letzten 200000 Jahre. Berichte zur Polarforschung 345. Alfred Wegener Institute for Polar and Marine Research, Bremerhaven, Germany.

Iriondo, M., 2000. Patagonian dust in Antarctica. Quaternary International $68-71,83-86$. 
Jenkins, G.M., Watts, D.G., 1969. Spectral Analysis and Its Applications. Holden Day, San Francisco, CA.

Kaiser, J., Lamy, F., 2010. Links between Patagonian Ice Sheet fluctuations and Antarctic dust variabilty during the last glacial period (MIS 4-2). Quaternary Science Reviews 29, 1464-1471.

Kilian, R., Lamy, F., 2012. A review of Glacial and Holocene paleoclimate records from southernmost Patagonia $\left(49-55^{\circ} \mathrm{S}\right)$. Quaternary Science Reviews 53, 1-23.

Kliem, P., Buylaert, J.P., Hahn, A., Mayr, C., Murray, A.S., Ohlendorf, C., Veres, D., Wastegård, S., Zolitschka, B., the PASADO Science Team, 2013a. Magnitude, geomorphologic response and climate links of lake level oscillations at Laguna Potrok Aike, Patagonian steppe (Argentina). Quaternary Science Reviews 71, 131-146.

Kliem, P., Enters, D., Hahn, A., Ohlendorf, C., Lisé-Pronovost, A., St-Onge, G., Wastegård, S., Zolitschka, B., the PASADO science team, 2013b. Lithology, radiocarbon chronology and sedimentological interpretation of the lacustrine record from Laguna Potrok Aike, southern Patagonia. Quaternary Science Reviews 71, 54-69.

Lambert, F., Bigler, M., Steffensen, J.P., Hutterli, M., Fischer, H., 2011. The calcium-dust relationship in high-resolution data from Dome C, Antarctica. Climate of the Past Discussions 7, 1113-1137.

Lambert, F., Delmonte, B., Petit, J.R., Bigler, M., Kaufmann, P.R., Hutterli, M.A., Stocker, T.F., Ruth, U., Steffensen, J.P., Maggi, V., 2008. Dust-climate couplings over the past 800,000 years from the EPICA Dome C ice core. Nature 452, 616-619.

Lenz, O.K., Wilde, V., Riegel, W., 2011. Short-term fluctuations in vegetation and phytoplankton during the middle Eocene greenhouse climate: a 640-kyr record from the Messel oil shale (Germany). International Journal of Earth Sciences 100, 1851-1874.

Li, F., Ginoux, P., Ramaswamy, V., 2010. Transport of Patagonian dust to Antarctica. Journal of Geophysical Research: Atmospheres 115, D18217. http://dx.doi.org/10.1029/2009JD012356.

Lisé-Pronovost, A., St-Onge, G., Gogorza, C., Haberzettl, T., Jouve, G., Francus, P., Ohlendorff, C., Gebhardt, C., Zolitschka, B., the PASADO Science Team, 2015. Rock-magnetic proxies of wind intensity and dust since 51,200 cal BP from lacustrine sediments of Laguna Potrok Aike, southeastern Patagonia. Earth and Planetary Science Letters 411, 72-86.

Mayr, C., Lücke, A., Stichler, W., Trimborn, P., Ercolano, B., Oliva, G., Ohlendorf, C. et al., 2007a. Precipitation origin and evaporation of lakes in semi-arid Patagonia (Argentina) inferred from stable isotopes $\left(\delta^{18} \mathrm{O}, \delta^{2} \mathrm{H}\right)$. Journal of Hydrology 334, 53-63.

Mayr, C., Lücke, A., Wagner, S., Wissel, H., Ohlendorf, C., Haberzettl, T., Oehlerich, M., et al., 2013. Westerlies regulated atmospheric $\mathrm{CO}_{2}$ during the last deglaciation. Geology 41, 831-834.

Mayr, C., Wille, M., Haberzettl, T., Fey, M., Janssen, S., Lücke, A., Ohlendorf, C., et al., 2007b. Holocene variability of the Southern Hemisphere westerlies in Argentinean Patagonia $\left(52^{\circ} \mathrm{S}\right)$. Quaternary Science Reviews 26, 579-584.

Mazzarini, F., D’Orazio, M., 2003. Spatial distribution of cones and satellite-detected lineaments in the Pali Aike Volcanic Field (southernmost Patagonia): insights into the tectonic setting of a Neogene rift system. Journal of Volcanology and Geothermal Research 125, 291-305.

Meglioli, A., 1992. Glacial Geology and Geochronology of Southernmost Patagonia and Tierra del Fuego, Argentina and Chile. PhD dissertation, Leigh University, Bethlehem, PA.
Mercer, J.H., 1976. Glacial history of southernmost South America. Quaternary Research 6, 125-166.

Molinie, A.J., Ogg, J.G., 1990. Sedimentation-rate curves and discontinuities from sliding-window spectral analysis of logs. Log Analyst 31, 1-25.

North Greenland Ice Core Project members, 2004. High-resolution record of Northern Hemisphere climate extending into the last interglacial period. Nature 431, 147-151.

Obrochta, S.P., Miyahara, H., Yokoyama, Y., Crowley, T.J., 2012. A re-examination of evidence for the North Atlantic "1500-year cycle" at site 609. Quaternary Science Reviews 55, 23-33.

Petit, J.R., Jouzel, J., Raynaud, D., Barkov, N.I., Barnola, J.M., Basile, I., Bender, M., et al., 1999. Climate and atmospheric history of the past 420,000 years from the Vostok ice core, Antarctica. Nature 399, 429-436.

Priestley, M.B., 1981. Spectral Analysis and Time Series. Academic Press, New York.

Prokopenko, A.A., Williams, D.F., Karabanov, E.B., Khursevich, G.K., 2001. Continental response to Heinrich events and Bond cycles in sedimentary record of Lake Baikal, Siberia. Global and Planetary Change 18, 217-226.

Rabassa, J., Clapperton, C.M., 1990. Quaternary glaciations of the southern Andes. Quaternary Science Reviews 9, 153-174.

Recasens, C., Ariztegui, D., Maidana, N.I., Zolitschka, B., the PASADO Science Team, 2015. Diatoms as indicators of hydrological and climatic changes in Laguna Potrok Aike (Patagonia) since the Late Pleistocene. Palaeogeography, Palaeoclimatology, Palaeoecology 417, 309-319.

Reijmer, C.H., van den Broeke, M.R., Scheele, M.P., 2002. Air parcel trajectories and snowfall related to five deep drilling locations in Antarctica based on the ERA-15 dataset. Journal of Climate 15, 1957-1968.

Ross, P.S., Delpit, S., Haller, M.J., Nemeth, K., Corbella, H., 2011. Influence of the substrate on maar-diatreme volcanoes-an example of a mixed setting from Pali Aike volcanic field, Argentina. Journal of Volcanology and Geothermal Research 201, 253-271.

Schneider, C., Glaser, M., Kilian, R., Santana, A., Butorovic, N., Casassa, G., 2003. Weather observations across the southern Andes at $53^{\circ} \mathrm{S}$. Physical Geography 24, 97-119.

Schulz, M., 2002. On the 1470-year pacing of Dansgaard-Oeschger warm events. Paleoceanography 17, 4-1-4-9.

Snowball, I., Muscheler, R., 2007. Palaeomagnetic intensity data: an Achilles heel of solar activity reconstructions. Holocene 17, 851-859.

Sprenk, D., Weber, M.E., Kuhn, G., Rosén, P., Frank, M., MolinaKescher, M., Liebetrau, V., Röhling, H.-G., 2013. Southern Ocean bioproductivity during the last glacial cycle - new detection method and decadal-scale insight from the Scotia Sea. In: Hambrey, M.J., Barker, P.F., Barrett, P.J., Bowman, V., Davies, B., Smellie, J.L., Tranter, M. (Eds.), Antarctic Palaeoenvironments and Earth-Surface Processes. Geological Society, London, Special Publications 381, 245-261.

St-Onge, G., Stoner, J.S., Hillaire-Marcel, C., 2003. Holocene paleomagnetic records from the St. Lawrence Estuary, eastern Canada: centennial- to millennial-scale geomagnetic modulation of cosmogenic isotopes. Earth and Planetary Science Letters 209, 113-130.

Sugden, D.E., McCulloch, R.D., Bory, A.J.-M., Hein, A.S., 2009. Influence of Patagonian glaciers on Antarctic dust deposition during the last glacial period. Nature Geoscience 2, 281-285.

Toggweiler, J.R., 2009. Shifting westerlies. Science 323, 1434-1435.

Weber, M.E., Kuhn, G., Sprenk, D., Rolf, C., Ohlwein, C., Ricken, W., 2012. Dust transport from Patagonia to Antarctica - 
a new stratigraphic approach from the Scotia Sea and its implications for the last glacial cycle. Quaternary Science Reviews 36, 177-188.

Weedon, G., 2003. Time-Series Analysis and Cyclostratigraphy: Examining Stratigraphic Records of Environmental Cycles. Cambridge University Press, Cambridge.

Weischet, W., 1996. Regionale Klimatologie. Teil 1. Die Neue Welt: Amerika, Neuseeland, Australien, Teubner, Stuttgart, Germany.

Weninger, B., Jöris, O., 2008. A ${ }^{14} \mathrm{C}$ age calibration curve for the last $60 \mathrm{ka}$ : the Greenland-Hulu U/Th timescale and its impact on understanding the Middle to Upper Paleolithic transition in western Eurasia. Journal of Human Evolution 55, 772-781.
Wonik, T., 2001. Gamma-ray measurements in the Kirchrode I and II boreholes. Palaeogeography, Palaeoclimatology, Palaeoecology 174, 97-105.

Zolitschka, B., Anselmetti, F.S., Aristegui, D., Corbella, H., Francus, P., Ohlendorf, C., Schäbitz, F., the PASADO Scientific Drilling Team, 2009. The Laguna Potrok Aike Scientific Drilling Project PASADO (ICDP Expedition 5022). Scientific Drilling 8, 29-34.

Zolitschka, B., Schäbitz, F., Lücke, A., Corbella, H., Ercolano, B., Fey, M., Haberzettl, T., et al., 2006. Crater lakes of the Pali Aike Volcanic Field as key sites for paleoclimatic and paleoecological reconstructions in southern Patagonia, Argentina. Journal of South American Earth Sciences 21, 294-309. 